\title{
State Policy on Institutionalization of Trusteeship in the Educational Sphere
}

\author{
Svetlana Dmitrievna Galiullina ${ }^{1}$, Shamil Zufarovich Valiev ${ }^{1}$, Oksana Mikhailovna Ivanova ${ }^{1} \&$ Larisa \\ Mikhailovna Bilalova ${ }^{2}$ \\ ${ }^{1}$ Ufa State University of Economics and Service, Russian Federation \\ ${ }^{2}$ Branch of Bashkir State University in Birsk, Russian Federation \\ Correspondence: Svetlana Dmitrievna Galiullina, Chernyshevskiy str., 145, Ufa, 450078, Bashkortostan, Russian \\ Federation.
}

Received: December 20, 2014 Accepted: March 27, 2015 Online Published: May 22, 2015

doi:10.5539/ass.v11n14p117 URL: http://dx.doi.org/10.5539/ass.v11n14p117

\begin{abstract}
The objective of the article is to consider the historical experience of formation and successful functioning of the institution of trusteeship in the educational sphere of the Russian empire in the nineteenth - beginning of the twentieth centuries. Historically Russia faced the necessity to speed up the paces of developing and raising the quality of public education. With this purpose the system of 15 educational districts headed by trustees was formed, which comprised 14 university complexes with composite educational infrastructure.

The principles of historicism and dialectic materialism, objectivity, scientific reliability and chronological sequence are the methodological base of the research. The method of interdisciplinary integration, use of knowledge of such sciences as sociology, psychology, pedagogy, political science and law has also been efficient. The following sources have been used: legislative acts, reference and statistical materials as well as materials of periodical press have been used.

The necessity of reviving the institution of trusteeship and educational districts headed by trustees at the beginning of the nineteenth century as a governmental initiative in solving the state policy in the conditions of reforms in the educational sphere has been substantiated. The significance of a state official - Trustee of an educational district, who had legal status, has been shown. It allowed to reform the educational sphere in a short period of time. All the above mentioned was the power and force of the state system of administrating educational institutions both in central and regional systems.
\end{abstract}

Keywords: educational reforms, state educational policy, the institute of trusteeship, an educational district, a trustee of an educational district

\section{Introduction}

Nowadays in the conditions of transformation crises in Russia the urgent task of increasing competitiveness of the Russian educational system arises. To attain this task the research of ways and mechanisms of its entering the world ratings is necessary. The revival of the institute of trusteeship in public education may become one of such regulators, as it successfully functioned in the Russian empire in the nineteenth - the beginning of the twentieth centuries. Historically Russia faced the necessity to speed up the pace of forming and improvement of quality of public education. For this purpose the system of 15 educational districts headed by trustees, which included 14 universities with unique educational infrastructures, was created. At present more than ever understanding and the right assessment of the historic experience and measured applying of the experience of the past in the interests of development and modernization of the national educational sphere is required. The urgency of the problem researched is corroborated by the fact that modern Russian system of education is facing the task of optimization of university and educational systems of the regions and improvement of graduating students' quality at all the levels of training.

The present situation in Russia more than ever is ready for the revival of the institution of trusteeship. The fundamental scientific works by historians, teachers and economists devoted to the research of the practice of the past testify this and the ways of applying them in the Russian system of education are shown (Galiullina, 2010, pp. 241-244, Galiullina, 2012; Yakusheva, 2009). Also, establishing of educational districts in the form of 
non-commercial organizations and associations has been begun. For example, the Association "Orenburg university (educational) district" (Orenburg) (Orenburg University (education) district, 2014) and "Kazan university educational district" (Kazan Federal University, 2014) has been formed. They have their own Regulations, in which the system of management of educational districts and the activity of the council of trustees or the meeting of the members of the council are detailed. The Association "University educational district" (Moscow) (University district, 2014) and University municipal psychological and pedagogical university (Novikov, 2012) have been created as well.

The modern system of education in foreign countries has been developed conformable to the experience of the Russian empire on the legislative basis which is formed by the state. For example, in the United States of America, France, China, Iran, Zimbabwe there is a system of school districts. It allows the federal state to provide control and supervision, but the main thing, to influence financing of educational institutions. The government supports districts with a low level of income by investment and stimulates educational districts with a high level of income by taxation laws. Such a way of financing is considered to be the most progressive one (Loeb \& Socias, 2004, pp. 85-94). In the state of New York the educational system consists of five big municipal school districts. Management is realized by the councils of trustees of these districts (Downes, 2000, pp. 417-429).

In Western China school districts in rural areas are assigned managing functions in the sector of education. It gives to the central bodies of management an opportunity to consider the peculiarities of outlying districts in realizing the educational policy (Quarshie \& Oyedele, 2011, pp. 1236-1243; Liu, Murphy, Tao \& An, 2009, pp. 463-473).

Educational districts in Canada are considered to be an instrument of public participation in managing educational institutions. Structurally the Canadian education consists of twelve independent educational systems (educational districts), which represent ten provinces and two northern territories. Each district has its councils of trustees headed by a trustee (Lucas \& Lusthaus, 1981, pp. 53-79).

\section{Method}

The principles of historicism and dialectical materialism, objective character, scientific authenticity and chronological sequence are the methodological base of the research. The method of interdisciplinary integration, usage of knowledge of such sciences as sociology, psychology, pedagogy, political science and law was also efficient. The versatile character of the problem under consideration concerning the revival of the system of trusteeship requires its examining on the basis of extensive base of sources: legislative acts, reference and statistical materials as well as materials of periodical press.

In the English language the phrase A trustee of an educational districts means "An administrator of an educational district". The term Administrator in the dictionary by S. I. Ozhegov is interpreted as an official, who manages something, is responsible for something, manager (Ozhegov, 2003, p. 21). In the dictionary "The ecclesiastical Slavic and Russian language" the term charge is used in the meaning care, zeal, endeavor of somebody or something (Encyclopedic dictionary, 1992, p. 382). A trustee - in the first meaning: a person who takes care of somebody or something (A trustee of an educational district). In the second meaning: "a person, appointed by the government, who is in charge of problems of orphans and people who are under guardianship" (Dictionary of Church Slavonic and Russian language, 1847, pp. 382-383).

\section{Results \& Discussion}

The beginning of the reign of Alexander $I$ is characterized by the continuation of educating traditions of Catherine II, this fact in a great extent was made conditional on the economic development of the country, which required a great number of educated people. Among the state reforms by Alexander I there was restructuring of the national educational system.

In accordance with the decree by Emperor Alexander I on January 24, 1803 "On establishing educational districts, with allocating certain provinces to each" (Full collection of laws of the Russian empire, 1830) the whole territory of the empire and all the educational institutions situated on it were divided into 6 "zones", which subsequently were called educational districts according to the number of being available or planned to be opened universities, which were assigned primary importance in educational districts. By this Decree the first six educational districts were established (Note 1): Saint Petersburg, Moscow, Kharkov, Kazan, Vilen, Derpt.

In 1824 a new division took place according to the same 6 districts, conformable to the dividing of provinces into okrugs of governor-general administration. 
By 1867 the educational space of Russia had been represented by 12 educational districts (The code of laws of the Russian Empire, 1893), one krai and two governor-general provinces. The system of education in Irkutsk, Yenisei provinces and Yakutsk region, as well as Turkestan region and other territories had been under the authority of the bodies, which had been called "The main administrations of public educational institutions" of the corresponding territorial unit. In 1874 Orenburg educational district was established. In 1885 - West Siberian educational district

By the end of the twentieth century there had been 15 districts (Statistical Yearbook of Russia, 1916, pp. 29-30). An educational district had comprised all the educational institutions of provinces and regions.

12 educational districts were administrated by Trustees. In three educational districts the administration of educational institutions was realized through the main administrations of public educational institutions - special structural units of the General Governments personnel: Turkestan, East - Siberian, Priamursk. The centers of the educational districts from 1803 to 1835 were universities, which along with scientific and educational tasks had administrative and organization functions. They were to administrate all the educational institutions of a region, in connection with this fact under the university boards specialized schools were set up and university professors, who were called visitators, were to fulfill the functions of inspectors. The trustees of educational districts were to inspect the districts entrusted to them at least one time in two years, to manage rectors, staying the rest of the time in Saint Petersburg. Each trustee was given 10000 rubles to pay for journeys to educational districts with the aim to examine them (The collection of resolutions of the Ministry of National Education, 1864, p. 2).

All the educational institutions were in close connections with each other and strict administrative dependence of lower levels of the system of public education on the higher ones was set up.

In 1883 with the accession to power as the Minister of Public Education S. S. Uvarov, the institution of trusteeship was improved and the authority of the Trustees of educational districts was widened. By that time Count Uvarov had been the Trustee of Saint Petersburg educational district for 10 years. He more than once informed the Emperor of the grievous state of universities.

Enjoying the Emperor's great confidence, S. S. Uvarov persuaded him of the necessity to make additions to the previous university regulations. In this connection in 1835 new university Regulations were approved, according to which universities were deprived of the right to administrate middle and low schools and set up scientific societies, and administration of educational institutions was handed over to the direct authority of the Trustees of educational districts. The rector of a university became a representative of a Trustee at a university. A trustee was assigned the central role in university hierarchy and in administrating educational institutions of a district. With delegation of powers over all educational institutions of a district to a Trustee, strengthening of governmental supervision over the provision of security check with the aim of preventing western liberal political ideas took place. The main objective in state reforming was in further approval of the paradigm "nationality, orthodoxy, autocracy", which were national priorities. The significance of an administrative vertical also grew, the scheme of administrating educational institutions was considerably simplified and their financial base was improved.

On June 25, 1835 with adopting new Regulations on educational districts the authority of a Trustee was strengthened, and his power was widened. His official duty was administrating all educational institutions of a district. A trustee and the Council under him were in charge of the state of middle and low educational institutions. In accordance with the law, a Trustee was to live on the territory of an educational district entrusted to him.

Subsequently depending on political conditions and further improvement of educational system, new Regulations were adopted in 1863 and 1884. In the Regulations of 1863 the regulations on a Trustee were limited, but his status remained unchanged. The new regulations remained a trustee's extraordinary authority, leaving him the right of veto in solving important, first of all personnel, issues of administrating.

In accordance with the Regulations of 1884 normative changes in administrating universities took place. A trustee's authority and his leading role remained unchanged. At the same time the status of a rector was raised, though he was still elected by a university board as a collegiate body.

Since 1881 for efficient functioning of educational districts the government provided state support in the form of assigning banknotes to educational districts:

23750 rubles for Saint Petersburg, for Moscow - 26550 rubles, for Kazan - 19600 rubles, for Kharkov - 21350 rubles, for Kiev - 23850 rubles, for Odessa - 20100 rubles, for Vilensk - 22940 rubles, for Derptsk - 17750 rubles, for Orenburg - 18250 rubles (Encyclopedic dictionary, 1993, p. 105). 
Having assigned state banknotes, the government took care for enhancement of supervision over educational institutions. As far back as in 1803 the aim of optimization of administrating an Educational district as well as for collective nature of making decisions concerning educational and economic matters, the Council of a Trustee and the Office of a district, which at the same time was the Office of a trustee, were established.

In Regulation norms a whole chapter "On Trustees of educational districts, their assistants and okrug inspectors" was devoted to a Trustee, administrating an Educational district and his official duties were defined. It is necessary to mention that since 1803 till 1835 a Trustee of an educational district was simultaneously a trustee of a university. By the Regulations of 1835 he "was made an absolute supervisor of all educational institutions of an okrug" (Encyclopedic dictionary, 1992, p. 546).

The activity of a Trustee of an educational district was state and public in its nature and by the Regulation norms he was granted authority of administrative character in managing, leading and organizing educational process as well as financial activity of educational institutions of an okrug.

Regarding administration, a Trustee was to realize executive and administrative activity with a view to solving tasks concerning realizing and executing normative and legal base of educational institutions: all governmental orders, directions, Statues and Regulations.

A Trustee solved problems concerning personnel policy in educational institutions of an okrug, the main directions of which were formation of the system of administrating personnel and developing its strategy, planning of personnel work, employment, selection and hiring of personnel, educating, career administrating and promotion. In his office he was granted the right to appoint to a post and fire a Trustee's assistant, an Okrug inspector and the Head of the office of an okrug.

It is necessary to mention that a Trustee's duties included tracking of teachers' educational qualification, for example, to be a teacher of the German and French languages, one had to graduate from university general course. A Trustee of an educational district was authorized to appoint religious teachers, teachers, teachers' assistants, clerks, accountants and housekeepers. As for the candidates to the position of Honorable trustees of gymnasiums, he made a nomination to the Minister of Public Education (The code of laws of the Russian Empire, 1893 , p. 68, 229, 324).

Under the authority of a trustee of an educational district there were matters connected with raising the level of professional and teaching staff and administrative and managing personnel's skills and their vacations.

With respect to educational activity, a Trustee was granted the right to approve curricula, study programs, the norms of teaching load, to assigned the volume of load for students and teachers, to define forms and methods of control of subjects, to organize supplementary courses in middle and low educational institutions, taking into account the requirements of a particular locality, to assign the number of classes for departments. A Trustee closely collaborated with local authorities, for example, the Governor's agreement; he organized national readings in the towns of a province. The head of an okrug realized social and partnership ties with public and charitable organizations, trade representatives, the petty bourgeois and merchants of the territory of an educational district. Also, he considered public opinion, the students' parents, their representatives: "having that view that an educational institution as an establishment existing for satisfaction of the need in being educated on the part of the society, first of all must be organized in such a way that the society fully trusts it... closer relations of an educational institution with the society is absolute necessity" (Report of Trustee of the Kazan educational district state Councilor of Stender for review of educational institutions entrusted to his management district from June to October 1863, p. 36, 49).

A Trustee's duty was to watch over students' equitable testing. He approved the regulations of entrance examinations, assessment of academic progress, instructions and Regulations on granting scholarship, the number of budgetary vacancies, work of the library, buying textbooks, appointing librarians. He defined the time and place for public events outside and inside educational institutions. The decisions of the Board of a university and resolutions of the Board of an administration, the Teachers' meeting and the Executive committee were also approved by a Trustee. All the journals of the Board of a university and the records of the Board had to be regularly submitted to a Trustee.

Significant role was assigned to a Trustee in close supervision over moral and patriotic education: "love to the one's closest circle and respect to the elders, devotion to the Throne, reverential gratitude to the Emperor and the ardent love to the motherland and by all means to support in them affection and obedience to their parents and to those people who act as their parents" (The code of laws of the Russian Empire, 1893, p. 179). He sanctioned the 
rules of wearing uniform in educational institutions. So, a Trustee was entrusted with the responsibility for introduction and approval of national ideas in the youth environment.

In financial activity according to the law a Trustee was supposed to receive a certain fund, which he might annually distribute in accordance with the budget of Educational institutions. This budget was carefully checked and analyzed by a Trustee, and then he approved and controlled the expenses and income. Educational institutions, receiving certain sums for their maintenance, in their term, were responsible for their integrity and distribution in accordance with the staff list, contracts and distribution.

As for the order of receiving, storage and spending (accounting and accountability) of monetary funds, coming to educational institutions, a trustee followed the rules of the General Counting Regulations of the Ministry of Public Education and additions, which were detailed in the Statutes and Regulations of educational institutions.

A Trustee also had the right to extend credits on petitions of Inspectors and Directors of educational institutions for their needs as well as to take decisions on their shift within one and the same paragraph of the financial estimate. A trustee was granted the right to appoint the Housekeeper, a person, responsible for economic security of a university.

A Trustee straight took part in attracting additional sources of income and private donations for the needs of education. This fact emphasizes one more important social and economic function of a Trustee of an educational district, which was realized when awarding with nominal scholarship. By law educational institutions were allowed to accept charitable contributions. For this a Trustee, on the basis of petitions of the founders of educational institutions or other people, who wanted to provide pecuniary aid, took a positive decision in those cases when the contributions were ensured with cash, or securities, but only that sum, annual interest on which corresponded the sum of the scholarship established. These sums should have been deposited in the State bank or its branches (offices) or in accordance with the order which was in force in particular offices. In those areas of the Russian Empire, where mortgage system was in effect, the sums were allowed to be deposited in property in land (The code of laws of the Russian Empire, 1893, p. 63).

Under each Trustee of an educational district there was a Council of trustees as a consultative body, in which, under his chairmanship, a Trustee's assistant, okrug inspectors, directors of educational institutions, university professors and teachers (on special invitation) were in session. In case of a Trustee's illness or absence his duties were executed by one of Okrug Inspectors.

Matters of administrative and educational character, defined by a Trustee, were subject to consideration of the Council of trustees. Besides in state specialized schools of an educational district a Trustee approved the structure of their Councils of trustees. Concerning municipal, land and class educational institutions, the supervision over their Councils of trustees was entrusted to one of the members of the Council of trustees of an educational district. The personal staff of the Councils of trustees of specialized schools comprised an honourable trustee, the head of a specialized school and two members of the Pedagogical committee.

The head of the okrug exercised direct control over educational institutions of an okrug in the form of personal inspection of educational institutions (at least one time in two years), or by means of officials (a trustee's assistant, an inspector of government specialized schools, visitators from the number of professors). Subsequently a Trustee represented the interests of educational institutions in the Ministry. For a Trustee's consideration with further reporting to the Minister of Public Education the matters were submitted, which concerned the elections of professors, teachers, honorable members and correspondents on the competitive base as well as diploma issuance.

According to the statuary norms a trustee did not get a salary for his trustee activity, he was supposed to get some money depending on his rank. A Trustee of an educational district had the IV rank in the Table of ranks. The members of the Council of trustees had the right to wear uniform of the VI rank of the Ministry of Public Education, in this way the state supported their high status.

\section{Conclusion}

So, a Trustee of an educational district was entrusted with wide powers. And as he had a direct access to the Emperor, his influence on the course of university life and educational institutions of an okrug was not inferior but even exceeded the power of the Minister.

Thus, at the beginning of XIX century on the Emperor's initiative educational districts were formed and the position of a Trustee of an educational district was set up, who became the central figure of the educational policy of the Russian Empire with forming the administrative and economic bodies under it. A Trustee was a state official and had a legal status. Also he was entrusted with executive power. The key functions of a trustee 
were enrichment of the substantial activity of the educational system, executive, administrating social and economic. All this was the power and force of the state system of administrating educational institutions both in central and regional systems. All this was a decisive condition in historical success of the national educational system of that period.

\section{References}

Association "Orenburg University (education) district". (2014, December 21). Retrieved December 21, 2014, from http://okrug.osu.ru

Dictionary of Church Slavonic and Russian language (comp. the 2nd department of the Imperial Academy of Sciences). V. III. (1847). Saint Petersburg, SPb: Publishing house of The Imperial Academy of Sciences.

Downes, T. (2000). Does fiscal dependency matter? Aid elasticities for dependent and independent school districts. Original Research Article Economics of Education Review, 19, 417-429. http://dx.doi.org/10.1016/s0272-7757(00)00007-8

Encyclopedic dictionary. Reprint reproduction of the edition of F. A. Brockhaus-I. A. Efron 1890. V. XLVIII. (1992). Yaroslavl: TERRA TERRA.

Encyclopedic dictionary. Reprint reproduction of the edition of F. A. Brockhaus-I. A. Efron 1890. V. LXIX. (1993). Yaroslavl: TERRA TERRA.

Full collection of laws of the Russian empire (FCL RE). The first meeting. V. XXVII. 1802-1803. \# 20.598. (1830). Saint Petersburg, SPb: Publishing house of the 2nd department of His Own Emperor's Office.

Galiullina, S. D. (2010). The activities of the school district Trustee. Bashkir University Bulletin, 1, 241-244.

Galiullina, S. D. (2012). Government care about public education in Russia (on the example of Orenburg school district. 1874-1917) (Doctoral dissertation). Russian state University of tourism and service, Moscow, Russia.

Liu, M., Murphy, R., Tao, R., \& An, X. (2009). Education management and performance after rural education finance reform: Evidence from Western China. International Journal of Educational Development, 29, 463-473. http://dx.doi.org/10.1016/j.ijedudev.2009.04.013

Loeb, S., \& Socias, M. (2004). Federal contributions to high-income school districts: the use of tax deductions for funding K-12 education. Original Research Article Economics of Education Review, 23, 85-94. http://dx.doi.org/10.1016/s0272-7757(03)00064-5

Lucas, B., \& Lusthaus, C. (1981). A volume in International Studies in Education and Social Change. CHAPTER 3 - Public Involvement in School Governance in Canada. The Politics of School Government, 53-79.

Novikov, V. N. (2012). University the school district as an important resource of psychological-pedagogical education. Psychological science and education, 11.

Ozhegov, S. I. (2003). Dictionary of the Russian language (24th ed.). Moscow: Onyx 21 vek. Mir i obrazovanie.

Quarshie, J., \& Oyedele V. (2011). University, Education District, and Schools Collaboration in the Preparation of Local Level Educational Leaders: The Zimbabwean Experience. Procedia - Social and Behavioral Sciences, 29, 1236-1243. http://dx.doi.org/10.1016/j.sbspro.2011.11.358

Report of Trustee of the Kazan educational district state Councilor of Stender for review of educational institutions entrusted to his management district from June to October 1863. W. p., w. y.

Statistical Yearbook of Russia. 1915. (1916). Petrograd, PG: Edition CSK MIA.

The code of laws of the Russian Empire (CL RE) by order of Emperor Nicholas I. V. XI. P. 1. The code of regulations of academic and Educational Institutions Department of the Ministry of National Education. (1893). Publishing of the codification Department under the state Council.

The collection of resolutions of the Ministry of National Education. The Reign Of Emperor Alexander I. 1802-1825. V.I. (1864). Saint Petersburg, SPb: Publishing house of The Imperial Academy of Sciences.

Yakusheva, S. D. (2009). University district - integration of science, education and practice: Monograph (2nd ed.). Moscow: APK\&PPRO.

Association "University district". (2014, December 21). Retrieved December 21, 2014, from http://www.rusprofile.ru/id/801287 
Kazan Federal University. (2014, December 21). Retrieved December 21, 2014, from $\mathrm{http} / / / \mathrm{kpfu} . r u / k u o o /$ obschaya-informaciya

\section{Note}

Note 1. Departmental okrug in the Russian empire - a territorial administrative structure, subordinated to a state institution (department). Okrug - an administrative territorial unit, established for a particular sector of management.

\section{Copyrights}

Copyright for this article is retained by the author(s), with first publication rights granted to the journal.

This is an open-access article distributed under the terms and conditions of the Creative Commons Attribution license (http://creativecommons.org/licenses/by/3.0/). 